\title{
COUMARINS OF Prangos latiloba
}

\author{
S. V. Serkerov, A. A. Kagramanov, \\ R. M. Abbasov, and A.M. Aliev
}

UDC 577.15/17:582.89

By chromatographic separation on a column of alumina, from the resin of the roots of Prangos latiloba Eug. Kor., collected in the Turkmen SSR, we have isolated six crystalline substances of courmarin nature in the individual state.

Substance (I), $\mathrm{C}_{19} \mathrm{H}_{20} \mathrm{O}_{5}, \mathrm{mp} 138-140^{\circ} \mathrm{C}$, on being heated with a $5 \%$ ethanolic solution of $\mathrm{KOH}$ formed a hydroxylactone $\mathrm{C}_{14} \mathrm{H}_{14} \mathrm{O}_{4}$ with $\mathrm{mp} 186-188^{\circ} \mathrm{C}$ and an acid $\mathrm{C}_{5} \mathrm{H}_{8} \mathrm{O}_{2}$ with $\mathrm{mp} 68^{\circ} \mathrm{C}$ identified on the basis of the comparison of IR spectra as marmesin and senecioic acid. On the basis of these results and the IR spectra, compound (I) was identified as pranchimgin [1].

Substance (II), $\mathrm{C}_{16} \mathrm{H}_{14} \mathrm{O}_{4}, \mathrm{mp} 107-108^{\circ} \mathrm{C}$, was identified by its composition, melting point, and IR spectrum as isoimperatorin.

Substance (III), $\mathrm{C}_{16} \mathrm{H}_{14} \mathrm{O}_{5}, \mathrm{mp} 140-142^{\circ} \mathrm{C}$, on being boiled with $10 \%$ sulfuric acid formed a substance $\mathrm{C}_{16} \mathrm{H}_{14,5}$ ( $\mathrm{mp} 140-142^{\circ} \mathrm{C}$ ), the IR spectrum of which coincided with the spectrum of isooxypeucedanin. The formation of isooxypeucedanin, and also the results of a comparison of the IR spectra of (III) and oxypeucedanin, permitted the substance to be identified as oxypeucedanin.

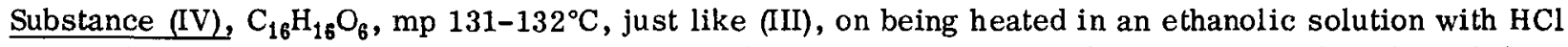
was converted into isooxypeucedanin, which was identified by a comparison of IR spectra. This showed that substance (IV) was oxypeucedanin hydrate.

Substances (V), $\mathrm{C}_{16} \mathrm{H}_{14} \mathrm{O}_{5}, \mathrm{mp} 143-146^{\circ} \mathrm{C}$, and (VI), $\mathrm{C}_{14} \mathrm{H}_{14} \mathrm{O}_{4}, \mathrm{mp} 186-188^{\circ} \mathrm{C}$, were obtained in very small amounts. By a comparison of their IR spectra they were identified as isooxypeucedanin and marmesin, respectively.

The IR spectra were taken on a UR-20 spectrophotometer in paraffin oil.

\section{LITERA TURE CITED}

1. G. A. Kuznetsova, Natural Coumarins and Furocoumarins, [in Russian], Leningrad (1967).

V. L. Komarov Institute of Botany, Academy of Sciences of the Azerbaidzhan SSR, Baku. Mardakyan Tree Park of the V. L. Komarov Institute of Botany, Academy of Sciences of the Azerbaidzhan SSR, Baku. N. Narimanov Azerbaidzhan State University, Baku. Translated from Khimiya Prirodnykh Soedinenii, No. 1, pp. 94-95, January-February, 1976. Original article submitted July 9, 1975.

This material is protected by copyright registered in the name of Plenum Publishing Corporation, 227 West 17th Street, New York, N.Y. 10011. No part of this publication may be reproduced, stored in a retrieval system, or transmitted, in any form or by any means, electronic, mechanical, photocopying, microfilming, recording or otherwise, without written permission of the publisher. A copy of this article is available from the publisher for \$7.50. 